\title{
Phoresy in the field: natural occurrence of Trichogramma egg parasitoids on butterflies and moths
}

\author{
Nina E. Fatouros • Martinus E. Huigens
}

Received: 29 July 2011 / Accepted: 16 November 2011/Published online: 29 November 2011

(C) The Author(s) 2011. This article is published with open access at Springerlink.com

\begin{abstract}
Phoretic insects utilize other animals to disperse to new environments. We recently discovered how egg parasitoids use an exciting phoretic strategy to reach egg-laying sites of their butterfly hosts. In the laboratory, female Trichogramma wasps detect and mount mated female cabbage white butterflies that emit an anti-aphrodisiac pheromone. Hardly any information exists about the natural occurrence of phoresy in wasps of this genus. Therefore, we monitored the presence of phoretic Trichogramma wasps on lepidopteran hosts in the field. Only female wasps were found at low prevalence on six lepidopteran species. Wasps were mostly found on female hosts and mainly on abundant solitary host species. This is the first report of phoretic Trichogramma wasps on butterflies in nature. We suggest that phoresy is only one of several strategies used by these polyphagous egg parasitoids. The evolution of phoresy is discussed in relation to the nutritional ecology of egg parasitoids.
\end{abstract}

Handling Editor: Stefano Colazza

Electronic supplementary material The online version of this article (doi:10.1007/s10526-011-9427-x) contains supplementary material, which is available to authorized users.

N. E. Fatouros $(\bowtie) \cdot$ M. E. Huigens

Laboratory of Entomology, Wageningen University, P. O. Box 8031, $6700 \mathrm{EH}$ Wageningen, The Netherlands e-mail: nina.fatouros@wur.nl
Keywords Hitchhiking - Anti-aphrodisiac · Oviposition-induced plant cues · Lepidoptera . Gregarious · Solitary

\section{Introduction}

Small animals with low mobility often seek out vehicles to migrate to new environments, for further development or reproduction (Binns 1982; Clausen 1976; Southwood 1962). Transportation on the bodies of other organisms, for purposes other than direct parasitism, is termed phoresy (see Clausen 1976 and references therein). Phoresy is commonly observed in arthropods like mites (Binns 1982). In parasitoid wasps it is almost exclusively restricted to species that develop in the smallest life stage of an insect: the egg (Clausen 1976; Godfray 1994; Vinson 1998). Because insect eggs are often inconspicuous, such egg parasitoids strongly rely on indirect cues emitted by adult hosts to obtain access to their eggs (Colazza et al. 2010; Fatouros et al. 2008b). In addition, egg parasitoids are generally assumed to be incapable of overcoming long distances by directed flight (Noldus 1989; Smith 1996; Suverkropp et al. 2009). This puts a strong selective pressure on these wasps to search for transport vehicles to get near their target host stage.

Phoretic relationships in egg parasitoids are frequently observed in the hymenopteran family Scelionidae, in some species of Trichogrammatidae, Eulophidae and single species of Encyrtidae, 
Eupelmidae and Torymidae [see Table 1 in electronic supplementary material, an update of the overview by Clausen (1976)]. In total, about 35 egg parasitoid species are reported to be phoretic. Thus, from the nearly 4,000 described egg parasitoid species belonging to the two families, Scelionidae and Trichogrammatidae (Austin et al. 2005; Querino et al. 2010), only about $1 \%$ are known to be phoretic. The hosts they use for transport include moths, grasshoppers, butterflies, pentatomid bugs, mantids, beetles, a dragonfly, an ant, and a fly (Table 1 in supplementary material). Once located, the wasps attach to their hosts either on the wings (of moths, butterflies and mantis), the abdomen (grasshoppers) or sometimes even on the hosts' antennae (of a bug, fly or ant) (Table 1 in supplementary material).

Some phoretic relationships can be obligate like between the European mantis (Mantis religiosa L.) and scelionid wasps of the genus Mantibaria, which parasitize the mantis' egg masses (Bin 1985; Couturier 1941). Here, the female wasp removes her wings after having mounted the female mantis, and hitches a ride to the oviposition site. The wingless wasp is then able to enter the frothy coating of freshly laid mantis eggs. Afterwards the parasitoid often returns to the same female mantis to parasitize successive egg masses. In other cases of phoresy, the adult host stage can strongly attract parasitoids: up to 250 females of the trichogrammatid Xenufens sp. were found on a female Caligo eurilochus (Cramer) (Lepidoptera: Nymphalidae) butterfly. This phoretic association is highly advantageous for the trichogrammatid wasps: they reach a mean parasitism rate of $78 \%$ of the butterfly eggs (Malo 1961).

To localize their vehicles, phoretic arthropods use cues of host activity, including auditory and tactile cues (Harbison et al. 2009; Owen and Mullens 2004) and infochemicals emitted by the host (Arakaki et al. 1996; Bruni et al. 2000; Soroker et al. 2003). In some cases, vehicles are even lured by the phorents by sexual deception (Saul-Gershenz and Millar 2006). Only few studies have investigated chemical cues that are used by phoretic egg parasitoids to locate their transporting host (Table 1 in supplementary material). Females of the egg parasitoid Telenomus euproctidis Wilcox (Hymenoptera: Scelionidae) are attracted by the sex pheromone of virgin Tussock moths (Euproctis pseudoconspersa) and hide in the anal tuft until the female moth started laying her egg clutch (Arakaki et al. 1995, 1996). Another scelionid wasp, Telenomus calvus Johnson, utilizes an aggregation pheromone emitted by male spined soldier bugs to find its host. When a male bug mates, the wasp transfers onto the female, which is possibly recognized by female-specific volatiles that are released from small glands underneath the wings (Aldrich 1995; Aldrich et al. 1984; Bruni et al. 2000; Buschman and Whitcomb 1980).

We recently reported about a combination of chemical espionage and phoresy in egg parasitoids of the genus Trichogramma. These polyphagous wasps parasitize eggs of a wide range of Lepidoptera, and are therefore massively used in biological control worldwide (Parra 2010; van Lenteren 2000) with currently 15 species commercially available on the world market (van Lenteren 2012). Two Trichogramma species utilize anti-aphrodisiac pheromones emitted by mated female hosts: the gregarious Large Cabbage White Pieris brassicae L. (Lepidoptera: Pieridae), that deposits egg clutches, and the solitary Small Cabbage White $P$. rapae L., that lays only a single egg at a time (Fatouros et al. 2005b; Huigens et al. 2009, 2010, 2011). Anti-aphrodisiacs are transferred from males to females during mating to enforce female monogamy (Andersson et al. 2000, 2003). Mated females were most attractive to the wasps (Fatouros et al. 2005b; Huigens et al. 2010). Synthetic anti-aphrodisiac compounds arrested inexperienced $T$. brassicae when applied onto virgin females, and stimulated the wasps to mount their hosts (Fatouros et al. 2005b; Huigens et al. 2010, 2011). After hitching a ride on a mated female Pieris butterfly to a host plant, e.g. Brussels sprouts (Brassica oleracea L. var. gemmifera), a $T$. brassicae wasp descends from the butterfly and parasitizes her freshly laid eggs. In contrast, inexperienced wasps of the closely related T. evanescens have to associatively learn to respond to anti-aphrodisiacs of cabbage white butterflies (Huigens et al. 2009, 2010). These behavioural studies were all performed under laboratory and greenhouse conditions. Very limited information is available about the prevalence of phoresy among Trichogramma species in nature. To the best of our knowledge, there is only one published report of Trichogramma females found on the moth Dendrolimus sibericus albolineatus Mats. (Lepidoptera: Lasiocampidae) in Russia (Tabata and Tamanuki 1940).

For egg parasitoids with numerous eggs available and a short lifespan, such as wasps of the genus 
Trichogramma, phoresy should be especially adaptive on gregarious hosts and on hosts that lay large single eggs per oviposition bout. In that case one successful phoretic event would give a female wasp the opportunity to deposit many of her eggs (Fatouros et al. 2005b). The aim of this study was to investigate the prevalence of phoresy in Trichogramma wasps in natural and cultivated habitats in the Netherlands and to test whether phoretic wasps are more frequently found on gregarious Lepidoptera than on solitary ones. So far, there are seven described Trichogramma species occurring in the Netherlands: T. evanescens Westwood, T. brassicae (Synonymy: T. maidis) Bezdenko, T. aurosum Sugonjaev and Sorokina, T. semblidis (Aurivillius), T. cacoeciae Marchal, T. embryophagum (Hartig), and T. dendrolimi Matsumura (Polaszek 2010). Here, we collected adults of a wide range of potential solitary and gregarious lepidopteran host species in the field, and examined them for the presence of phoretic Trichogramma wasps. Moreover, we updated the latest reports on phoretic relationships in egg parasitoids since Clausen (1976).

\section{Materials and methods}

Sampling sites

Adult butterflies were collected from 2003 to 2009 in natural and cultivated field sites in the Netherlands that were mostly located around the city of Wageningen $\left(51^{\circ} 57^{\prime} \mathrm{N}-51^{\circ} 58^{\prime} \mathrm{N}, 5^{\circ} 38^{\prime} \mathrm{E}-5^{\circ} 39^{\prime} \mathrm{E}\right)$. Moths were only collected in 2007. The main field sites varied between (1) a small garden/meadow with flowering plants (2), a cultivated cabbage field with Brassica oleracea plots, (3) a botanical garden, (4) a meadow with flowering plants, (5) black mustard (Brassica nigra L.) patches surrounded by meadows near the river Rhine, and (6) a meadow with flowering plants close to that same river. Other occasional sampling sites were located close to the cities of Nijmegen $\left(51^{\circ} 48^{\prime} \mathrm{N}-51^{\circ} 50^{\prime} \mathrm{N}, 5^{\circ} 54^{\prime} \mathrm{E}-\right.$ $\left.5^{\circ} 55^{\prime} \mathrm{E}\right)$, Ede $\left(52^{\circ} 35^{\prime} \mathrm{N}, 5^{\circ} 39^{\prime} \mathrm{E}\right)$ and Alphen $\left(51^{\circ} 27^{\prime} \mathrm{N}-\right.$ $\left.51^{\circ} 30^{\prime} \mathrm{N}, 4^{\circ} 56^{\prime} \mathrm{E}-4^{\circ} 59^{\prime} \mathrm{E}\right)$.

Butterfly and moth catching

Butterflies were collected with a net (Diameter $30 \mathrm{~cm}$, Vermandel, The Netherlands) that contained a plastic vial (height $7 \mathrm{~cm}$, diameter $7 \mathrm{~cm}$ ) at the bottom to avoid loosing phoretic wasps while catching the butterfly as much as possible (see Fig. 1). After the butterfly entered the vial it was closed with a lid and replaced by a new vial. To prevent accidental catching of non-phoretic wasps, butterflies were always caught in flight. In case a butterfly was present on a plant/ flower, we waited until it took off to make sure no plant material ended up in the butterfly net with vial inside. Moreover, we performed 138 control sweeps through the vegetation at the six main sampling sites without catching butterflies. This did not yield any Trichogramma wasps. Moths were collected during night. At night an High Performance Lamp light powered by a generator was used to attract moths to a big white cloth $\left(6 \mathrm{~m}^{2}\right)$. Moths that landed on the cloth were caught using the same plastic vials as those inside the butterfly nets. After collection, vials with butterflies and moths were placed in a refrigerator to reduce mobility and thereafter the lepidopteran species and sex was determined. Furthermore, butterfly/moth and vial were examined under a stereomicroscope for the presence of Trichogramma wasps. Wasps were put in small vials containing 95\% ethanol for molecular species identification based on the ribosomal ITS-2 gene (for more details see Gonçalves et al. 2006; Huigens et al. 2004; Stouthamer et al. 1999).

Wasp species identification

\section{DNA extraction}

The wasps that were stored in ethanol were dried on filter paper. Afterwards, they were individually crushed in a $0.5 \mathrm{ml}$ Eppendorf tube with a closed pasteur pipet. Then, $50 \mu \mathrm{l}$ of Chelex solution (5\%) and $4 \mu \mathrm{l}$ of proteinase $\mathrm{K}\left(20 \mathrm{mg} \mathrm{ml}^{-1}\right)$ were added. The samples were incubated overnight at $56^{\circ} \mathrm{C}$, followed by $10 \mathrm{~min}$ at $95^{\circ} \mathrm{C}$.

\section{PCR amplification}

For every sample a PCR reaction was performed. PCR reactions were performed in a $25 \mu$ l volume consisting of $18.43 \mu \mathrm{l}$ of distilled water, $2.5 \mu \mathrm{l} 10 \times \mathrm{PCR}$ reaction buffer (HT Biotechnologies Ltd., Cambridge, UK), $2.5 \mu \mathrm{l}$ DNA template, $0.5 \mu \mathrm{ldNTP}(10 \mathrm{mM}), 0.5 \mu \mathrm{l}$ forward primer, $0.5 \mu \mathrm{l}$ reverse primer and $0.07 \mu \mathrm{l} \mathrm{Taq}$

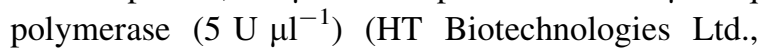


Fig. 1 Percentage of butterflies carrying a phoretic Trichogramma wasp in our field survey in The Netherlands. Number above the columns represent the number of collected individuals per butterfly species and gender. Sampling was done with an adapted net containing a vial at the bottom. Pictures of butterflies are not in natural proportion to each other

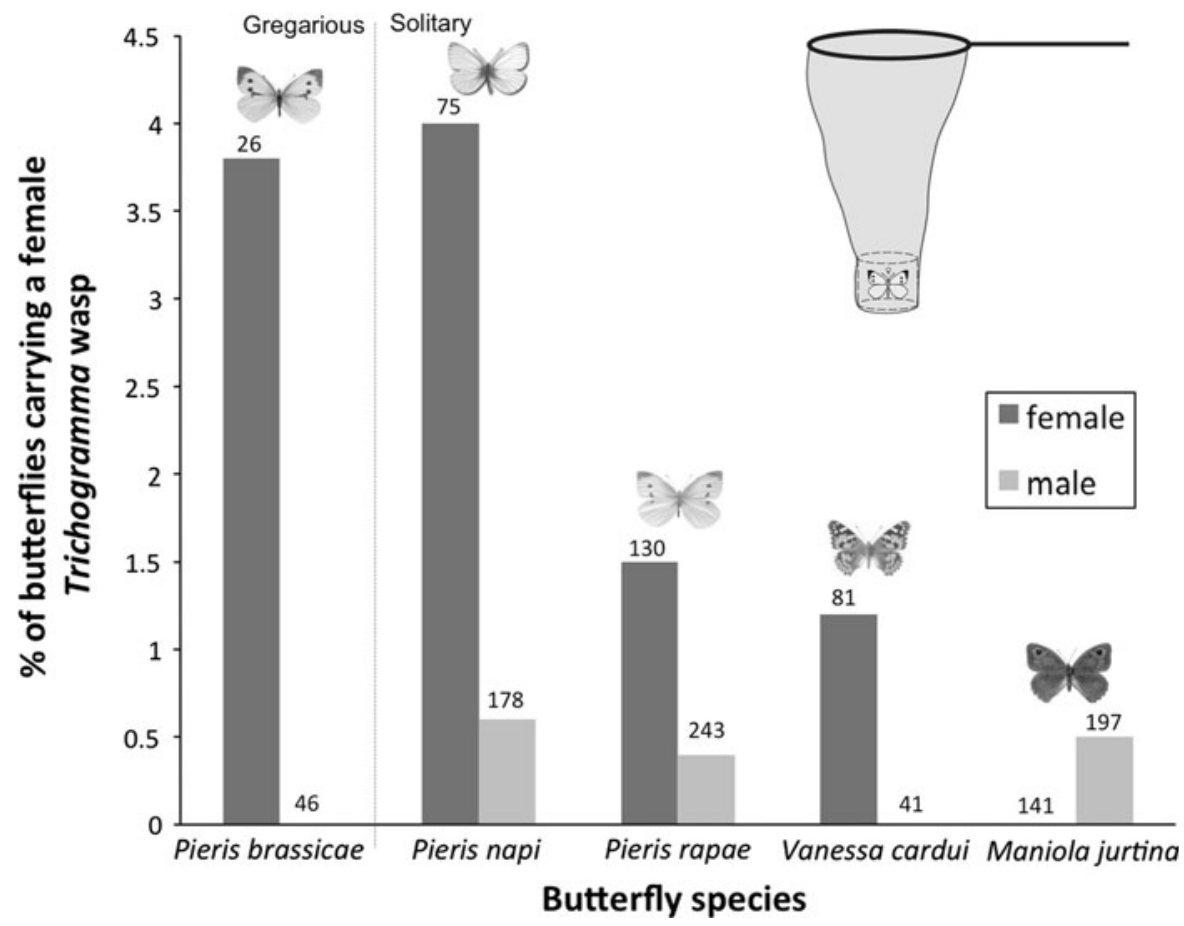

Cambridge, UK) within a $0.2 \mathrm{ml}$ Eppendorf tube. The primers used to amplify the ITS-2 region were:

\section{5'-TGTGAACTGCAGGACACATG-3' (forward) and \\ 5'-GTCTTGCCTGCTCTGAG-3' (reverse).}

The PCR cycling program was $3 \mathrm{~min}$ at $94^{\circ} \mathrm{C}, 33$ cycles of $40 \mathrm{~s}$ at $94^{\circ} \mathrm{C}, 45 \mathrm{~s}$ at $53^{\circ} \mathrm{C}$ and $45 \mathrm{~s}$ at $72^{\circ} \mathrm{C}$, followed by $10 \mathrm{~min}$ at $72^{\circ} \mathrm{C}$ after the last cycle. PCR products were run on a $1.5 \%$ agarose gel and stained with ethidium bromide.

\section{Cloning and sequencing}

After conducting a PCR reaction and running the samples on an electrophoresis gel, the ITS-2 products were excised from the gel using the MinElute Gel Extraction Kit (QIAGEN GmbH, Hilden, Germany) for DNA fragment purification. The PCR fragment was ligated to a pGEM-T vector (Promega, Madison, WI, USA) and transformed into Escherichia coli $\times 12$ cells (Stratagene, La Jolla, CA, USA). Correct insertion of the ITS-2 fragments was confirmed by PCR. To purify the plasmid, a GeneElute Plasmid Miniprep Kit (Sigma-Aldrich Chemie, Steinheim, Germany) was used. ITS-2 fragments were sequenced using an
Applied Biosystems automatic sequencer. Finally, the ITS-2 sequences were aligned and matched against sequences present in GenBank and those present in the large database of Prof. Dr. R. Stouthamer (Department of Entomology, University of California Riverside, USA).

\section{Results}

In total, 24 butterfly species were collected and examined for the presence of Trichogramma wasps (Supplementary Table 2). From the 1,472 collected butterflies, only ten individual female wasps were found on five different butterfly species, three Pierid and two nymphalid butterflies: the solitary Small Cabbage White Pieris rapae (three wasps), the gregarious Large Cabbage White $P$. brassicae (one wasp), the solitary Green-veined White $P$. napi L. (four wasps), the solitary Painted Lady Vanessa cardui L. (Lepidotera: Nymphalidae) (one wasp) and the solitary Meadow Brown Maniola jurtina L. (Lepidoptera: Satyridae) (one wasp) (Fig. 1). Male wasps were not found. Butterflies never carried more than one phoretic female wasp. Interestingly, most wasps (nine out of ten) were found on solitary butterflies (Fig. 1). 
Fifteen out of the 24 collected butterfly species have a solitary life style. Many more individuals of the solitary species were collected $(N=1,205)$ than from the nine gregarious butterfly species $(N=267)$ (Supplementary Table 3). Most of the wasps (seven out of ten) were found on female butterflies (Fig. 1). We identified two wasp species: six $T$. evanescens were found on three Pieris species (one on a P. brassicae female, one on a $P$. rapae female, one on a $P$. rapae male, one on a $P$. napi female, and one on a $P$. napi male), whereas $T$. brassicae was found on two $P$. napi females and on one M. jurtina female (Fig. 1; supplementary Table 2). Unfortunately, the female wasp that was found on $V$. cardui could not be identified to species level. Our PCR method yielded an ITS-2 sequence that was related, but not identical, to any of the known ITS-2 sequences of trichogrammatid wasps.

From the 777 moths collected belonging to 111 species (Supplementary Table 4), only one nightactive female Xestia c-nigrum L. (Lepidoptera: Noctuidae) (out of 66 moths collected of that species) carried a female wasp, which was identified as $T$. brassicae (Supplementary Table 2). Internal Transcribed Spacer-2 gene sequences of all phoretic wasps were submitted to GenBank (accession numbers JN315370-JN315380).

\section{Discussion}

Our field sampling revealed that phoretic Trichogramma wasps occur at low prevalence on adults of various butterfly and moth species in nature. Females of the two species ( $T$. evanescens and $T$. brassicae) that display phoretic behaviour on Pieris brassicae and P. rapae in laboratory studies (Fatouros et al. 2005b, 2007; Huigens et al. 2009, 2010) were also found on butterflies and moths in the field. Trichogramma evanescens was only found on three Pieris species and is known to be an abundant egg parasitoid of those species in different habitats in The Netherlands (Huigens and Fatouros, unpublished data; van Rijswijk 2000). Phoretic wasps are mostly collected on female butterflies but sometimes also occur on males. In the latter case, those wasps may be inexperienced. We have shown earlier that inexperienced $T$. evanescens females do not discriminate between climbing onto female and male butterflies of $P$. brassicae and $P$. rapae but do prefer to mount butterflies over non-host insects, such as desert locusts (Huigens et al. 2009). Only after a successful hitchhiking experience on a mated (and thus egg-laying) female butterfly, leading to an oviposition into a freshly laid butterfly egg, these wasps prefer to climb onto mated females over virgin females and males (Fatouros et al. 2007; Huigens et al. 2009, 2010). It might also be that wasps occasionally hitchhike with males to transfer onto females during mating, which has been frequently observed in phoretic egg parasitoids of bugs (Bruni et al. 2000; Kohno 2002; Malo 1961).

To transfer onto or between vehicles, the phoretic passengers need to find sites likely to meet their hosts. Flowers were shown to serve as transmission locations for crab spiders, mites and even pathogens to transfer onto flower visitors, e.g. bumble bees and butterflies during their nectar feeding (Durrer and Schmid-Hempel 1994; Morse 1986; Schwarz and Huck 1997; Treat 1969). As for most parasitoid species, sugars obtained from floral nectar are an essential energy source to sustain many physiological processes. Flower location in these parasitoids is mediated by both olfactory and visual stimuli (Romeis et al. 2005). Thus, since both the butterfly host and Trichogramma use floral nectar, flowers may be used for horizontal transfer. On the practical side, the butterfly is stationary during nectar feeding, making it easier for the parasitoid to mount.

Although members of the parasitoid family Trichogrammatidae are well-known to parasitize eggs of many Lepidoptera (Querino et al. 2010), including some of those collected in our survey (Supplementary Table 2), the low prevalence of phoretic wasps in our field study suggests Trichogramma species not to heavily rely on transportation on adult hosts to find host eggs. The low prevalence of phoretic Trichogramma wasps in our study could have several reasons:

(1) Host age and quality: Orr et al. (1986) reported a number of behavioural and biological adaptations of the phoretic scelionid Telenomus calvus, like a narrow range of host egg ages suitable for parasitism. Because of the rather weak ovipositor typical for scelionids (reviewed by Quicke 1997), T. calvus is restricted to soft and young host eggs less than $12 \mathrm{~h}$ old. Being able to attack only young hosts means that parasitoids need to 
seek for them by using a so-called ambush approach, which is 'to be there before the host egg is oviposited' (Vinson 1985, 2010). A phoretic habit is one possible approach to accomplish this and could explain why it has evolved frequently among scelionids. In contrast, Trichogramma wasps are able to parasitize older host eggs until the head capsule of the caterpillar has sclerotized (reviewed by Pak 1986). They kill the embryo, feed on dead tissues and then can take time to develop (Vinson 2010). Trichogramma brassicae wasps were shown to successfully parasitize up to four-day-old $P$. brassicae eggs (Fatouros et al. 2005a).

(2) Egg load: another life history trait related to phoretic behaviour is the relatively small number of eggs produced, for example, by T. calvus females (Orr et al. 1986). Usually, all eggs can be deposited in the first encountered host egg clutch. Compared to most scelionids, trichogrammatids are facultative gregarious parasitoids and produce a higher number of, sometimes more than 100 eggs per female (Jervis et al. 2008).

(3) Dietary specialization: Trichogramma wasps are very polyphagous (Smith 1996). Trichogramma evanescens, for example, parasitizes more than 65 different species (Hase 1925), whereas scelionids appear to be more specialized (Vinson 2010). Polyphagy increases the chance to encounter hosts and would decrease the adaptive value of using specific host-related cues (Vet and Dicke 1992; Vet et al. 1995). A phoretic relationship is likely to require specificity. The ability of the passenger to detect host-related cues depends on the degree of specialization of the interaction (Vet and Dicke 1992). Inexperienced $T$. evanescens can discriminate between a butterfly host and a locust but learn odors of mated Pieris females labeled with an antiaphrodisiac pheromone (Huigens et al. 2009, 2010). This ability of learning to respond to adult host cues is probably related to their relatively wide dietary breadth (Hase 1925). Yet, some Trichogramma species/populations may be rather host specific. For example, T. kaykai mainly parasitizes eggs of the Mormon Metalmark butterfly (Apodemia mormo deserti) in the Mojave Desert of the American Southwest (Huigens et al. 2000; Pinto et al. 1997;
Stouthamer et al. 2001), which lays its eggs on patchily distributed desert trumpet plants (Eriogonum inflatum). In such an extreme habitat, it is likely that $T$. kaykai shows to some extent a phoretic life-style.

(4) Use of different foraging strategies: to locate host eggs, most egg parasitoids strongly rely on the adult host stage by using aggregation or (anti-)sex pheromones and other host-related chemical cues released before or during oviposition (Colazza et al. 2010; Fatouros et al. 2008b; Powell 1999; Vinson 2010). However, more evidence accumulates that egg parasitoids also rely on plant cues induced by herbivore egg deposition (Colazza et al. 2010; Hilker and Meiners 2006, 2010). We recently discovered that eggs of $P$. brassicae and $P$. rapae induce chemical changes in Brussels sprouts plants (B. oleracea var. gemmifera) that arrest Trichogramma wasps three days after egg deposition in the close vicinity (Fatouros et al. 2005a, 2009; Pashalidou et al. 2010). Interestingly, these plant cues are induced by the same anti-aphrodisiac compounds that attract Trichogramma wasps directly to mated Pieris females (Fatouros et al. 2008a, 2009). The black mustard B. nigra even releases volatile cues induced by Pieris eggs that can attract the wasps from a longer distance (N.E. Fatouros, unpublished data). It is unlikely that oviposition-induced plant cues are used by egg parasitoids that seek for fresh host eggs (i.e. scelionids) because of the delay of the plants' response to oviposition (Vinson 2010).

(5) Sampling method: despite the use of special butterfly nets (Fig. 1), our methodology may be not highly efficient. We may still loose many phoretic wasps while catching butterflies. Preliminary greenhouse tests showed that increasing the size of the vial from $7 \mathrm{~cm}$ (used in the present study) to $15 \mathrm{~cm}$ in diameter increased the chance of recapturing a phoretic female $T$. brassicae wasp from a female $P$. brassicae butterfly inside a net from only 10 to $70 \%$, respectively, simply because use of a larger vial inside increases the chance that a butterfly with wasp immediately flies into the vial (Huigens, unpublished data). In case we found wasps, it was almost exclusively on Lepidopteran species of which many individuals were collected (see supplementary 
Tables 3 and 4 for a complete overview). A small sample size may also explain why some of the Lepidoptera that are known to be hosts for Trichogramma spp. did not yield any phoretic wasps (Supplementary Table 2). Our field study at least highlights that large sample sizes may be required to determine if phoresy occurs in certain species of egg parasitoid wasps, certainly when the prevalence is low and the methodology is not highly efficient. Phoresy might thus be much more widespread in egg parasitoids than known so far (Table 1 in supplementary material).

So far, most hosts known to be exploited by phoretic egg parasitoids have a gregarious life style (>90\%) (Supplementary Table 1). Phoresy provides the wasps access to large numbers of eggs oviposited in widely dispersed locations (e.g. grasshoppers) or to eggs sealed in 'containers' (i.e. ootheca) such as occurs with mantids (Clausen 1976). Yet, most phoretic Trichogramma wasps were found on solitary hosts, laying single eggs. The reason for this might be that most solitary butterfly species with a phoretic wasp were caught in high numbers of more than hundred individuals, which was not the case for the gregarious species. The solitary butterfly species carrying wasps (P. napi, P. rapae, V. cardui and $M$. jurtina) are very abundant in the Netherlands (Bos et al. 2006). Accordingly, the wasps face a trade-off between less frequent gregarious species versus abundant solitary ones. Additionally, not only the number of host eggs but also host egg size plays a role in how many offspring a Trichogramma wasp can produce. The larger the host eggs, the more wasps will generally develop inside it (Godfray 1994; Schmidt and Smith 1987). Unfortunately, we were unable to evaluate the number of offspring produced per host egg (clutch) of each collected species. We can at least conclude that female Trichogramma wasps need to find many eggs of the solitary butterfly and moth species on which we found wasps, to be able to get rid of all the eggs that they produce during their lifespan (Supplementary Table 2).

We do not expect Trichogramma wasps to frequently hitchhike with night-active lepidopteran hosts. Trichogramma wasps are diurnal wasps that generally become active at temperatures above $12^{\circ} \mathrm{C}$ (Pak and van Heiningen 1985; Suverkropp et al.
2001). The low prevalence of wasps in our night catches $(0.13 \%)$ is reflecting this. Yet, two other observations of Trichogramma wasps found on a Xestia baja and a Phlogophora meticulosa moth (Supplementary Table 2; J. Voogd, personal communication) show that certain wasps have found a way to overcome this problem.

To the best of our knowledge, our study presents the first extensive field survey of phoretic Trichogramma wasps on adult lepidopterans. Even though Trichogramma wasps can reach rather high parasitism rates in the field, e.g. of Pieris butterfly eggs in the Netherlands (Fatouros and Huigens, unpublished data; van Heiningen et al. 1985), our data suggest that only a small portion of Trichogramma wasps use adult hosts as transport vehicles to oviposition sites. Besides host specificity, patchy or extreme habitats, like deserts, might select for the evolution of a phoretic relationship (Houck and Oconnor 1991; Krishnan et al. 2010; Vinson 1985). Extensive field studies correlating egg parasitism by Trichogramma species to the prevalence of phoretic wasps are needed to confirm this hypothesis. From an applied perspective, knowledge about the prevalence of phoretic behavior in a given parasitoid wasp species can be important to increase the efficiency of its use in biological control programs. In case an egg parasitoid heavily relies on phoresy to find freshly laid host eggs, such as Telenomus spp., it could be essential to release the wasps before most adult pests start laying their eggs. Our study suggests that this does not apply so much to Trichogramma wasps as biological control agents against lepidopteran pests because they can also parasitize "older" host eggs and do not seem to heavily rely on adults as transporting hosts.

Acknowledgments The authors thank Joop Woelke, Marion Munneke, Silja Tribuhl, Erik de Swart, and Foteini Pashalidou for their help with the field work and species determinations, Richard Stouthamer and Patrick Verbaarschot for their help in analyzing and submitting the ITS2 sequences, respectively, and Joop van Lenteren for reading an earlier version of this manuscript. The German Research Foundation (FA 824/1-11 to N.E.F.) and the Netherlands Organisation for Scientific Research (NWO/ALW VENI grants 863.05.020 to M.E.H. and 863.09.002 to N.E.F.) are acknowledged for funding.

Open Access This article is distributed under the terms of the Creative Commons Attribution Noncommercial License which permits any noncommercial use, distribution, and reproduction in any medium, provided the original author(s) and source are credited. 


\section{References}

Aldrich JR (1995) Chemical communication in the true bugs and parasitoid exploitation. In: Cardé RT, Bell WJ (eds) Chemical ecology of insects II. Chapman and Hall, New York, pp 318-363

Aldrich JR, Kochansky JP, Abrams CB (1984) Attractant for a beneficial insect and its parasitoids: pheromone of the predatory soldier bug, Posidus maculiventris (Hemiptera: Pentatomidae). Environ Entomol 13:1031-1036

Andersson J, Borg-Karlson A-K, Wiklund C (2000) Sexual cooperation and conflict in butterflies: a male-transferred anti-aphrodisiac reduces harassment of recently mated females. Proc R Soc Lond B 267:1271-1275

Andersson J, Borg-Karlson AK, Wiklund C (2003) Antiaphrodisiacs in pierid butterflies: a theme with variation! J Chem Ecol 29:1489-1499

Arakaki N, Wakamura S, Yasuda T (1995) Phoresy by an egg parasitoid, Telenomus euproctidis (Hymenoptera: Scelionidae), on the tea tussock moth, Euproctis pseudoconspersa (Lepidoptera: Lymantriidae). Appl Entomol Zool 30:602-603

Arakaki N, Wakamura S, Yasuda T (1996) Phoretic egg parasitoid, Telenomus euproctidis (Hymenoptera: Scelionidae), uses sex pheromone of tussock moth Euproctis taiwana (Lepidoptera: Lymantriidae) as a kairomone. J Chem Ecol 22:1079-1085

Austin AD, Johnson NF, Dowton M (2005) Systematics, evolution, and biology of scelionid and platygastrid wasps. Annu Rev Entomol 50:553-582

Bin F (1985) Phoresy in an egg parasitoid: Mantibaria seefelderiana (De Stef.-Per.) (Hym. Scelionidae). Atti XIV Congr Naz Ital Ent 901-902

Binns ES (1982) Phoresy as migration-some functional aspects of phoresy in mites. Biol Rev 57:571-620

Bos F, Bosveld M, Groenendijk D, van Swaay C, Wynhoff I (2006) De Dagvlinders van Nederland: Vespreiding en Bescherming. KNNV Uitgeverij, Utrecht, The Netherlands

Bruni R, Sant'Ana J, Aldrich JR, Bin F (2000) Influence of host pheromone on egg parasitism by scelionid wasps: comparison of phoretic and nonphoretic parasitoids. J Insect Behav 12:165-173

Buschman LL, Whitcomb WH (1980) Parasites of Nezara viridula (Hemiptera: Pentatomidae) and other Hemiptera in Florida. Fla Entomol 63:154-162

Clausen CP (1976) Phoresy among entomophagous insects. Annu Rev Entomol 21:343-368

Colazza S, Peri E, Salerno G, Conti E (2010) Host searching by egg parasitoids: exploitation of host chemical cues. In: Consoli FL, Parra JRP, Zucchi R (eds) Egg parasitoids in agroecosystems with emphasis on Trichogramma. Springer, Dordrecht, The Netherlands, pp 97-147

Couturier A (1941) Nouvelles observations sur Rielia manticida Kief., hyménoptère parasite de la mante religieuse. II. Comportement de l'insecte parfait. Rev Zool Agric Appl 40:49-62

Durrer S, Schmid-Hempel P (1994) Shared use of flowers leads to horizontal pathogen transmission. Proc R Soc Lond B 258:299-302
Fatouros NE, Bukovinszkine'Kiss G, Kalkers LA, Soler Gamborena R, Dicke M, Hilker M (2005a) Oviposition-induced plant cues: do they arrest Trichogramma wasps during host location? Entomol Exp Appl 115:207-215

Fatouros NE, Huigens ME, van Loon JJA, Dicke M, Hilker M (2005b) Chemical communication-butterfly anti-aphrodisiac lures parasitic wasps. Nature 433:704

Fatouros NE, Bukovinszkine' Kiss G, Dicke M, Hilker M (2007) The response specificity of Trichogramma egg parasitoids towards infochemicals during host location. J Insect Behav 20:53-65

Fatouros NE, Broekgaarden C, Bukovinszkine'Kiss G, van Loon JJA, Mumm R, Huigens ME, Dicke M, Hilker M (2008a) Male-derived butterfly anti-aphrodisiac mediates induced indirect plant defense. Proc Natl Acad Sci USA 105:10033-10038

Fatouros NE, Dicke M, Mumm R, Meiners T, Hilker M (2008b) Foraging behavior of egg parasitoids exploiting chemical information. Behav Ecol 19:677-689

Fatouros NE, Pashalidou FG, Aponte Cordero WV, van Loon JJA, Mumm R, Dicke M, Hilker M, Huigens ME (2009) Anti-aphrodisiac compounds of male butterflies increase the risk of egg parasitoid attack by inducing plant synomone production. J Chem Ecol 35:1373-1381

Godfray HCJ (1994) Parasitoids: behavioral and evolutionary ecology. Princeton University Press, Princeton, USA

Gonçalves CI, Huigens ME, Verbaarschot P, Duarte S, Mexia A, Tavares J (2006) Natural occurrence of Wolbachia-infected and uninfected Trichogramma species in tomato fields in Portugal. Biol Control 37:375-381

Harbison CW, Jacobsen MV, Clayton DH (2009) A hitchhiker's guide to parasite transmission: the phoretic behaviour of feather lice. Int J Parasitol 39:569-575

Hase A (1925) Beiträge zur Lebensgeschichte der Schlupfwespe Trichogramma evanescens Westwood. Arb Biol Reichsan Land-Forstwirt Berl-Dahl 14:171-224

Hilker M, Meiners T (2006) Early herbivore alert: insect eggs induce plant defense. J Chem Ecol 32:1379-1397

Hilker M, Meiners T (2010) How plants "notice" attack by herbivores. Biol Rev 85:267-280

Houck MA, Oconnor BM (1991) Ecological and evolutionary significance of phoresy in the astigmata. Annu Rev Entomol 36:611-636

Huigens ME, Luck RF, Klaassen RHG, Maas M, Timmermans M, Stouthamer R (2000) Infectious parthenogenesis. Nature 405:178-179

Huigens ME, de Almeida RP, Boons PAH, Luck RF, Stouthamer R (2004) Natural interspecific and intraspecific horizontal transfer of parthenogenesis-inducing Wolbachia in Trichogramma wasps. Proc R Soc Lond B 271:509-515

Huigens ME, Pashalidou FG, Qian MH, Bukovinszky T, Smid HM, van Loon JJA, Dicke M, Fatouros NE (2009) Hitchhiking parasitic wasp learns to exploit butterfly antiaphrodisiac. Proc Natl Acad Sci USA 106:820-825

Huigens ME, Woelke JB, Pashalidou FG, Bukovinszky T, Smid HM, Fatouros NE (2010) Chemical espionage on speciesspecific butterfly anti-aphrodisiacs by hitchhiking Trichogramma wasps. Behav Ecol 21:470-478

Huigens M, de Swart E, Mumm R (2011) Risk of egg parasitoid attraction depends on anti-aphrodisiac titre in the large 
cabbage white butterfly Pieris brassicae. J Chem Ecol 37:364-367

Jervis MA, Ellers J, Harvey JA (2008) Resource acquisition, allocation, and utilization in parasitoid reproductive strategies. Annu Rev Entomol 53:361-385

Kohno K (2002) Phoresy by an egg parasitoid, Protelenomus sp. (Hymenoptera: Scelionidae), on the coreid bug Anoplocnemis phasiana (Heteroptera: Coreidae) (Behavior and Ecology). Entomol Sci 5:281-285

Krishnan A, Muralidharan S, Sharma L, Borges RM (2010) A hitchhiker's guide to a crowded syconium: how do fig nematodes find the right ride? Funct Ecol 24:741-749

Malo F (1961) Phoresy in Xenufens (Hymenoptera: Trichogrammatidae), a parasite of Caligo eurilochus (Lepidoptera: Nymphalidae). J Econ Entomol 54:465-466

Morse DH (1986) Predatory risk to insects foraging at flowers. Oikos 46:223-228

Noldus LPJJ (1989) Semiochemicals, foraging behaviour and quality of entomophagous insects for biological control. J Appl Entomol 108:425-451

Orr DB, Russin JS, Boethel DJ (1986) Reproductive biology and behavior of Telenomus calvus (Hymenoptera: Scelionidae), a phoretic egg parasitoid of Podisus maculiventris (Hemiptera: Pentatomidae). Can Entomol 118: 1063-1072

Owen JP, Mullens BA (2004) Influence of heat and vibration on the movement of the northern fowl mite (Acari: Macronyssidae). J Med Entomol 41:865-872

Pak GA (1986) Behavioural variations among strains of Trichogramma spp.: a review of the literature on host-age selection. J Appl Entomol 101:55-64

Pak GA, van Heiningen TG (1985) Behavioural variations among strains of Trichogramma spp.: adaptability to fieldtemperature conditions. Entomol Exp Appl 38:3-13

Parra JRP (2010) Mass rearing of egg parasitoids. In: Consoli FL, Parra JRP, Zucchi R (eds) Egg parasitoids in agroecosystems with emphasis on Trichogramma. Springer, Dordrecht, The Netherlands, pp 267-292

Pashalidou FG, Huigens ME, Dicke M, Fatouros NE (2010) The use of oviposition-induced plant cues by Trichogramma egg parasitoids. Ecol Entomol 35:748-753

Pinto JD, Stouthamer R, Platner GR (1997) A new cryptic species of Trichogramma (Hymenoptera: Trichogrammatidae) from the Mojave desert of California as determined by morphological, reproductive and molecular data. Proc Entomol Soc Wash 99:238-247

Polaszek A (2010) Species diversity and host associations of Trichogramma in Eurasia. In: Consoli FL, Parra JRP, Zucchi R (eds) Egg parasitoids in agroecosystems with emphasis on Trichogramma. Springer, Dordrecht, The Netherlands, pp 237-266

Powell W (1999) Parasitoid hosts. In: Hardie J, Minks AK (eds) Pheromones of non-lepidopteran insects associated with agricultural plants. CABI Publishing, Wallingford, UK, pp 405-427

Querino RB, Zucchi R, Pinto DM (2010) Systematics of the Trichogrammatidae (Hymenoptera: Chalcidoidea) with a focus on the genera attacking Lepidoptera. In: Consoli FL, Parr AJ, Zucchi R (eds) Egg parasitouds in agroecosystems with emphasis on Trichogramma. Springer, Dordrecht, The Netherlands, pp 191-218
Quicke DLJ (1997) Parasitic wasps. Chapman \& Hall, London, UK

Romeis J, Babendreier D, Wäckers FL, Shanower TG (2005) Habitat and plant specificity of Trichogramma egg parasitoids-underlying mechanisms and implications. Basic Appl Ecol 6:215-236

Saul-Gershenz LS, Millar JG (2006) Phoretic nest parasites use sexual deception to obtain transport to their host's nest. Proc Natl Acad Sci USA 103:14039-14044

Schmidt JM, Smith JJB (1987) Short interval time measurement by a parasitoid wasp. Science 237:903-905

Schwarz HH, Huck K (1997) Phoretic mites use flowers to transfer between foraging bumblebees. Insect Soc 44: 303-310

Smith SM (1996) Biological control with Trichogramma: advances, successes, and potential of their use. Annu Rev Entomol 41:375-406

Soroker V, Nelson D, Bahar O, Reneh S, Yablonski S, Palevsky E (2003) Whitefly wax as a cue for phoresy in the broad mite Polyphagotarsonemus latus (Acari: Tarsonemidae). Chemoecology 13:163-168

Southwood TRE (1962) Migration of terrestrial arthropods in relation to habitat. Biol Rev 37:171-211

Stouthamer R, Hu JG, van Kan F, Platner GR, Pinto JD (1999) The utility of internally transcribed spacer 2 DNA sequences of the nuclear ribosomal gene for distinguishing sibling species of Trichogramma. BioControl 43:421-440

Stouthamer R, van Tilborg M, de Jong JH, Nunney L, Luck RF (2001) Selfish element maintains sex in natural populations of a parasitoid wasp. Proc R Soc Lond B 268:617-622

Suverkropp BP, Bigler F, van Lenteren JC (2001) Temperature influences walking speed and walking activity of Trichogramma brassicae (Hym., Trichogrammatidae). J Appl Entomol 125:303-307

Suverkropp BP, Bigler F, van Lenteren JC (2009) Dispersal behaviour of Trichogramma brassicae in maize fields. Bull Insectol 62:113-120

Tabata S, Tamanuki K (1940) On the hymenopterous parasites of the pine caterpillar, Dendrolimus sibiricus alboneatus Mats. in southern Sakhalin. Rev Appl Entomol A29:A95

Treat AE (1969) Behavioral aspects of the association of mites with noctuid moths. In: Evans GO (ed) 2nd international congress of acarology. Akademiai Kiado, Budapest, Hungary, pp 275-286

van Heiningen TG, Pak GA, Hassan SA, van Lenteren JC (1985) Four year's results of experimental releases of Trichogramma egg parasites against lepidopteran pests in cabbage. Med Fac Landbouww Rijksuniv Gent 50:379-388

van Lenteren JC (2000) Success in biological control of arthropods by augmentation of natural enemies. In: Gurr GM, Wratten SD (eds) Biological control: measures of success. Kluwer Academic Publishers, Hingham, USA, pp 77-103

van Lenteren JC (2012) The state of commercial augmentative biological control: plenty of natural enemies, but a frustrating lack of uptake. BioControl (in press). doi:10.1007/ s10526-011-9395-1

van Rijswijk MEC (2000) Occurrence and molecular identification of Dutch Trichogramma species, Msc thesis, Laboratory of Entomology, Wageningen University, Wageningen, The Netherlands, pp 1-14 
Vet LEM, Dicke M (1992) Ecology of infochemical use by natural enemies in a tritrophic context. Annu Rev Entomol 37:141-172

Vet LEM, Lewis WJ, Cardé RT (1995) Parasitoid foraging and learning. In: Cardé RT, Bell WJ (eds) Chemical ecology of insects, vol 2. Chapman \& Hall, New York, USA, pp 65-101

Vinson SB (1985) The behavior of parasitoids. In: Kerkut GA, Gilbert LI (eds) Comprehensive insect physiology, biochemistry and pharmacology, vol 9. Pergamon Press, New York, USA, pp 417-469

Vinson SB (1998) The general host selection behavior of parasitoid Hymenoptera and a comparison of initial strategies utilized by larvaphagous and oophagous species. Biol Control 11:79-96
Vinson SB (2010) Nutritional ecology of insect egg parasitoids. In: Consoli FL, Parra JRP, Zucchi R (eds) Egg parasitoids in agroecosystems with emphasis on Trichogramma. Springer, Dordrecht, The Netherlands, pp 25-55

\section{Author Biographies}

Nina E. Fatouros studies the chemical ecology of ovipositionmediated interactions between plants, their lepidopteran herbivores and parasitoid wasps.

Martinus E. Huigens investigates the behavioral, evolutionary, chemical and cognitive ecology of parasitoid wasps, in particular the genus Trichogramma. 